\title{
PERANCANGAN SISTEM INFORMASI GEOGRAFIS (SIG) SEBAGAI MEDIA INFORMASI PRAKERIN BERBASIS WEB DI SMKN 6 TANGERANG SELATAN
}

\author{
Chaidir Kurnia Thoullah ${ }^{1}$, Agnia Bilqisti ${ }^{2}$, Dhimas Alifiyanto ${ }^{3}$ \\ Dosen Teknik Informatik STMIK Raharja ${ }^{1}$, Mahasiswa Teknik Informatika STMIK Raharja ${ }^{2,3}$ \\ e-mail : chaidir.soedaryono@raharja.info ${ }^{1}$,agnia@raharja.info ${ }^{2}$,dhimas.alifiyanto@raharja.info ${ }^{3}$
}

\begin{abstract}
Industry Work Practice or commonly called the PRAKERIN is an activity that must be followed by every vocational students during school as a form of implementation of science or as an addition to an insight into the working world they will face in the future. But obstacles that was often faced by student is in the search company locations the industrial work practice. From the problem, we need to make a web based geographic information system (GIS) that provides information about the location of company in Tangerang. In search of the location or place, it would require a geographic information. Nowadays, people mostly use Google Maps application. To overcome the obstacles mentioned above, the authors use a SWOT (Strength, Weakness, Opportunity, Thread) to identify the obstacles encountered in greater detail.To create a model or design of an expert system, the authors use UML (Unified Modeling Language) as a tools. and taking data sources form map's that author got from Google Maps API, location's data sources form SMKN 6 Tangerang selatan that has been cooperated with the company. The author hopes the student can easyly access the location place the industrial work practice.
\end{abstract}

Keywords : Industry Work Practice, PRAKERIN, Geografic Information Sistem (GIS), student, company, Analisa SWOT, Google Maps API.

\section{ABSTRAK}

Praktek Kerja Industri atau biasa disebut PRAKERIN merupakan kegiatan yang wajib diikuti oleh setiap siswa - siswi SMK semasa sekolah sebagai bentuk dari pengimplementasian ilmu ataupun sebagai penambah wawasan tentang dunia kerja yang akan mereka hadapi kedepannya. Akan tetapi kendala yang sering dihadapi oleh siswa yaitu dalam pencarian lokasi perusahaan Praktek Kerja industri. Dari gambaran masalah tersebut maka diperlukan adanya suatu sistem informasi geografis (SIG) berbasis web yang menyediakan informasi mengenai lokasi perusahaan di Kota Tangerang. Dalam pencarian lokasi tentu membutuhkan letak atau suatu posisi yang dikenal sebagai informasi geografis. Informasi geografis yang paling banyak digunakan masyarakat pada saat ini yaitu aplikasi Google Maps. Untuk mengatasi kendala yang disebutkan diatas maka penulis menggunakan Analisa SWOT (Strength, Weakness, Opportunity, Thread) untuk mengidentifikasi kendala yang dihadapi secara lebih terperinci. Untuk membuat model atau rancangan dari sistem maka penulis menggunakan UML (Unified Modelling Languange) sebagai alat bantu atau tools. dan sumber data yang digunakan dalam penelitian ini yaitu Peta Kota yang diperoleh dari Google Maps API dan data lokasi perusahaan yang di peroleh dari SMKN 6 Tangerang Selatan yang telah bekerja sama dengan pihak perusahaan. Dari sistem yang dibuat, penulis berharap siswa dapat dengan mudah mengakses lokasi perusahaan tempat praktek kerja industri.

Kata Kunci : Praktek Kerja Industri, PRAKERIN, Sistem Informasi Geografis (SIG), Siswa, Perusahaan, Analisa SWOT, Google Maps API. 


\section{PENDAHULUAN}

Praktek Kerja Industri atau biasa disebut PRAKERIN merupakan kegiatan yang wajib diikuti oleh setiap siswa - siswi SMK semasa sekolah sebagai bentuk dari pengimplementasian ilmu ataupun sebagai penambah wawasan tentang dunia kerja yang akan mereka hadapi kedepannya.

Berupa pelatihan dan pembelajaran yang dilaksanakan di Dunia Usaha Atau Dunia Industri dalam upaya pendekatan ataupun untuk meningkatkan mutu siswa - siswi Sekolah Menengah Kejuruan (SMK) dengan kompetensi (kemampuan) siswa sesuai bidangnya dan juga menambah bekal untuk masa - masa mendatang guna memasuki dunia kerja yang semangkin banyak serta ketat dalam persaingannya seperti di masa sekarang ini.

Dalam pelaksanaannya dilakukan dengan prosedur tertentu, bagi siswa yang bertujuan untuk magang disuatu tempat kerja, baik dunia usaha maupun didunia industri setidaknya sudah memiliki kemampuan dasar sesuai bidang yang digelutinya atau sudah mendapatkan bekal dari pembimbing disekolah untuk memiliki ilmu-ilmu dasar yang akan diterapkan dalam dunia usaha atau dunia Industri. Kebanyakan SMK memiliki program keahlian lebih dari satu dan terdiri dari beberapa kelas. Tentu saja terdapat tugas sekolah tersendiri dalam mendistribusikan tiap siswanya untuk melaksanakan praktek kerja industri secara menyeluruh. Bagian terkait yang bertugas juga dituntut untuk menyajikan kebutuhan data dan informasi agar dapat mengurangi kerancuan seperti dalam proses pengajuan.

Namun masih banyak siswa yang belum mengetahui dan kesulitan mencari lokasi letak perusahaan industri tempat melaksanakan tugas PRAKERIN (Praktek Kerja Industri) mereka . maka informasi mengenai akses transportasi ke tempat tersebut sangat dibutuhkan.

Hal ini akan menjadi tugas pokok dan fungsi dari SMKN 6 Tangerang yang bertanggung jawab dalam pemberitahuan informasi mengenai lokasi perusahaan tempat PRAKERIN (Praktek Kerja Industri) di daerah Kota Tangerang dan mengenai akses transportasi ke tempat tersebut. Sehingga siswa PRAKERIN (Praktek Kerja Industri) dapat dengan mudah mengakses lokasi perusahaan di Kota Tangerang.

\section{LANDASAN TEORI}

\section{A. Sistem Informasi Geografis (SIG)}

Menurut Oleh Soleh dkk (2015:1) "Sistem Informasi Geografis merupakan salah satu bentuk sistem dengan konsep yang bisa diterapkan untuk memberikan informasi berupa persebaran data lokasi ruang yang ada di Kota Tangerang dalam bentuk digital. Sistem ini akan dikembangkan berbasis web dengan tampilan multimedia digital, penggunaan dapat mengakses sistem pada perangkat yang tersambung dengan jaringan internet."

\section{B. Sistem Informasi}

Menurut Harfizar, dkk (2017:195) “ Sistem informasi adalah komponen-komponen yang membentuk sistem yang menghasilkan suatu informasi yang berfungsi sebagai penyedia informasi atau laporan".

\section{Praktek Kerja Industri (Prakerin)}

Menurut Nidhom , Sonhadji dan Sudjimat (2015:4) "Prakerin adalah suatu bentuk pendidikan dan pelatihan yang dilaksanakan di industri atau dunia kerja secara terarah dengan tujuan untuk membekali peserta didik dengan sikap dan ketrampilan sesuai dengan cara belajar langsung di industri." D.Web

Menurut Al Husain, dkk (2016:134) "Web atau sering disebut dengan situs bisa diartikan sebagai kumpulan dari halaman-halaman yang digunakan untuk menampilkan berbagai informasi diantaranya yaitu, informasi teks, gambar diam maupun gerak, animasi, suara, video atau gabungan dari semuanya, baik yang bersifat statetis maupun dinamis yang membentuk

Vol 5 No 1 - Februari 2019 
satu rangkaian bangunan yang saling terkait, yang masing-masing dihubungkan dengan jarigan-jaringan halaman".

\section{E.DataBase}

Menurut Warnas (2014:84) "database baik dalam bentuk database terstruktur dan tidak terstruktur dibutuhkan sebagai tempat penyimpanan tetap untuk merekam kegiatan proses transaksi bisnis."

Menurut Cosmas Eko Suharyanto, Dkk. (2017) "database adalah kumpulan data terstruktur. Agar dapat menambahkan, mengakses, dan memproses data yang tersimpan dalam database komputer, dibutuhkan sistem manajemen basis data (database management system)."

F.Google Maps API

Menurut Fauzan Masykur (2014:181) “Google Maps API adalah suatu library yang berbentuk JavaScript."

Menurut Enggar Kusuma . M dan Yanto Budisusanto (2015:130) "Google Maps API merupakan aplikasi antarmuka yang dapat diakses melalui javascript agar Google Maps dapat ditampilkan pada web yang sedang dibangun."

G. Internet

Menurut Meta Amalya Dewi, dkk (2014:121) "Internet adalah komputer yang terhubung melalui jaringan dan saling berkomunikasi dengan waktu dan wilayah yang tak terbatas".

H. UML (Unified Modeling Language)

Menurut Yusuf ddk (2015:29), "UML (Unified Modeling Language) adalah himpunan struktur dan teknik untuk permodelan desain program berorientasi objek (OOP) serta aplikasinya. UML adalah metodologi untuk mengembangkan sistem tersebut.

Jenis-jenis Diagram UML (Unified Modeling Language)

Menurut Ary Budi Warsito dkk (2014:29) "Unified Modeling Language (UML) adalah himpunan struktur dan teknik untuk permodelan desain program berorientasi objek (OOP) serta aplikasinya. UML adalah metodologi untuk mengembangkan sistem OOP dan sekelompok perangkat tool untuk mendukung pengembangan sistem tersebut".

Menurut Ade Hendini (2016), alat bantu yang digunakan dalam perancangan berorientasi objek berbasiskan UML adalah sebagai berikut:

a.Use case diagram

Use case diagram merupakan pemodelan untuk kelakuakn (behavior) sistem informasi yang akan dibuat. Use case digunakan untuk mengetahui fungsi apa saja yang ada di dalam sistem informasi dan siapa saja yang berhak menggunakan fungsi-fungsi tersebut.

b.Sequence Diagram

Sequence Diagram menjelaskan interaksi objek yang disusun berdasarkan urutan waktu. Secara mudahnya sequence diagram adalah gambaran tahap demi tahap, termasuk kronologi (urutan) perubahan secara logis yang seharusnya dilakukan untuk menghasilkan sesuatu sesuai dengan use case diagram.,

\section{c.Activity diagram}

Activity Diagram menggambarkan berbagai alir aktivitas dalam sistem yang sedang dirancang, bagaimana masing-masing alir berawal, decision yang mungkin terjadi, dan bagaimana mereka berakhir. Activity diagram juga dapat menggambarkan proses paralel yang mungkin terjadi pada beberapa eksekus.

Merupakan hubungan antar kelas dan penjelasan detail tiap-tiap kelas di dalam model desain dari suatu sistem, juga memperlihatkan aturan-aturan dan tanggung jawab entitas yang menentukan perilaku sistem. Class Diagram juga menunjukkan atribut-atribut dan operasi-operasi dari sebuah kelas dan constraint yang berhubungan dengan objek yang dikoneksikan. 


\section{METODE PENELITIAN}

Metodologi penelitian adalah sebuah proses dari prinsip dan prosedur yang digunakan untuk mendekati masalah dalam mencari suatu solusi atau jawaban. Dengan kata lain, metodologi adalah suatu pendekatan umum yang digunakan untuk mengkaji sesuatu topik penelitian. Hal - hal yang akan memengaruhi hasil dari penelitian yaitu salah satunya adalah keakuratan hasil dari penelitian tersebut. Hal ini sangat dipengaruhi oleh metode analisa dan pengolahan yang digunakan dalam pembuatan sebuah penelitian.

\section{A. Pengumpulan Data}

Dalam memperoleh data yang ada dalam penelitian maka penulis menggunakan beberapa metode yang digunakan adalah sebagai berikut:

1. Metode Observasi

Melakukan pengumpulan data melalui pengamatan secara langsung ke SMKN 6 Tangerang Selatan yang berlokasi di jalan Griya Asri No.7, Kel. Jelupang, Kec. Serpong Utara , dengan cara mengumpulkan data serta informasi mengenai hal yang berhubungan dengan tema penelitian

2. Metode Wawancara

Melakukan studi dengan metode wawancara dengan narasumber SMKN 6 Tangerang Selatan . Bapak Yuri Matufira S.Pd, M.T Selaku bidang Kurikulum untuk memperoleh data yang akurat dengan melakukan sesi tanya jawab secara langsung dengan stakeholder.

3. Metode Studi Pustaka

Penulis mempelajari serta memahami buku dan literatur yang berhubungan dengan laporan penelitian dari penelitian - penelitian yang sudah dilakukan untuk lebih mendalami teori maupun praktek yang berkaitan dengan judul yang diambil dengan membaca dan untuk membantu analisa sistem yang dilakukan.

B. Analisa Dan Perancangan Sistem

Metode analisis sistem yang dipakai adalah analisis SWOT di Analisis SWOT (SWOT analysis) yakni mencakup upaya - upaya untuk mengenali kekuatan, kelemahan, peluang, dan ancaman yang menentukan kinerja Sistem.. Berikut adalah tabel analisis SWOT pada sistem informasi geografis sebagai media prakerin di SMKN 6 Tangerang Selatan :

\begin{tabular}{|c|c|}
\hline Kekuatan (Strenght) & Kelemahan (Weakness) \\
\hline $\begin{array}{l}\text { 1. Bekerja sama dengan perusahaan - } \\
\text { perusahaan besar. } \\
\text { 2. Lokasi Perusahaan Prakerin yang strategis. }\end{array}$ & $\begin{array}{l}\text { 1. Pendataan Siswa Prakerin masih } \\
\text { menggunakan sistem manual. } \\
\text { 2. Siswa harus mencari lokasi dengan cara } \\
\text { manual. } \\
\text { 3. Siswa harus menunggu informasi tempat } \\
\text { prakerin sebelum mengajukan tempat yang } \\
\text { diinginkan. }\end{array}$ \\
\hline Peluang (Opportunities) & Ancaman (Threat) \\
\hline $\begin{array}{l}\text { 1. Mengganti dan memperbaharui sistem yang } \\
\text { lama menjadi baru dengan program yang } \\
\text { menggunakan database untuk } \\
\text { mempermudah pengambilan data. } \\
\text { 2. Dukungan pihak sekolah dalam melengkapi } \\
\text { sarana dan fasilitas sekolah yang lebih } \\
\text { cepat dan akurat. }\end{array}$ & $\begin{array}{l}\text { 1. Siswa kesulitan mencari lokasi sehingga } \\
\text { resiko tersesat besar. } \\
\text { 2. Keamanan data yang kurang dapat } \\
\text { menyebabkan data rawan terkena virus dan } \\
\text { hilang. }\end{array}$ \\
\hline
\end{tabular}


Kemudian setelah mengidentifikasi dari tabel diatas dengan menggunaan metode SWOT, selanjutnya akan dilakukan analisa untuk mencari strategi dengan menggunakan matriks SWOT. Matrik Swot ini dapat mengambarkan secara jelas bagaimana peluang dan ancaman eksternal yang dihadapi sekolah dapat disesuaikan dengan kekuatan dan kelemahan yang dimilikinya. Matrik ini dapat menghasilkan 4 set kemungkinan alternatif strategi. Yaitu strategi S-O (Kekuatan-Peluang), strategi W-O (Kelemahan-Peluang), strategi S-T (Kekuatan-Ancaman), strategi W-T (Kelemahan-Ancaman).

\begin{tabular}{|c|c|c|}
\hline Internal & Kekuatan (Strenght) & Kelemahan (Weakness) \\
\hline \multirow[b]{2}{*}{ Peluang (Opportunities) } & $\mathrm{S}-\mathrm{O}$ & $\mathrm{W}-\mathrm{O}$ \\
\hline & $\begin{array}{l}\text { Mengembangkan sistem yang } \\
\text { berjalan saat ini menjadi sistem } \\
\text { yang lebih cepat dan akurat } \\
\text { dalam pendataan serta informasi } \\
\text { lokasi perushaan prakerin. }\end{array}$ & $\begin{array}{l}\text { Membuat sistem yang } \\
\text { terkomputerisasi sehingga dapat } \\
\text { menambah kualitas sekolah } \\
\text { menjadi lebih baik lagi dan } \\
\text { mempermudah siswa dalam } \\
\text { mendapatkan informasi. }\end{array}$ \\
\hline \multirow[b]{2}{*}{ Ancaman (Threat) } & S-T & W-T \\
\hline & $\begin{array}{l}\text { Memberi pengamanan sistem } \\
\text { yang kuat agar data tidak hilang. }\end{array}$ & $\begin{array}{l}\text { Meningkatkan kualitas dan } \\
\text { fasilitas dibidang IT agar sekolah } \\
\text { tidak perlu lagi menggunakan } \\
\text { cara lama yang masih manual. }\end{array}$ \\
\hline
\end{tabular}

Tabel .2 Matriks SWOT

\section{HASIL DAN PEMBAHASAN}

Berdasarkan hasil Analisa yang telah dilakukan terhadap sistem informasi geografis pada SMKN 6 Tangerang, dapat dilihat ada beberapa permasalahan yang dihadapi. Permasalahan-permasalahan diantaranya sebagai berikut:

1. Pendataan siswa prakerin masih dilakukan secara manual sehingga masih banyak terdapat kesalahan dalam pengimputan data serta penempatan tempat lokasi prakerin.

2. Siswa masih harus menunggu informasi dari pihak sekolah sehingga menunggu lebih lama .

3. Pencarian letak lokasi tempat prakerin secara manual dapat menimbulkan resiko siswa tersesat.

Dari permasalahan yang dihadapi, maka diberikan alternative pemecahan masalah-masalah yang dapat membatu dan menjadi referensi untuk PT. Bentara Sinergies Multifinance. Alternatif pemecahan masalah diantaranya sebagai berikut:

1. Diperlukan satu sistem yang terkomputerisasi dan mempunyai koneksi secara langsung dengan lokasi perusahaan agar siswa dapat menemukan lokasi perusahaan juga memilih dan mendaftarkan diri ke perusahaan tersebut.

2. Mengubah sistem yang berjalan saat ini menjadi sistem terkomputerisasi menggunakan sistem web yang dapat diakses siswa juga dapat membantu pengolahan data oleh admin.

3. Sistem baru yang mempunyai database agar admin dalam melakukan pendataan siswa yang akan melaksanakan tugas Prakerin dan mempunyai peta lokasi agar siswa mudah menemuka lokasi tempat Prakerin . 


\section{SISTEM YANG BERJALAN}

A. USECASE DIAGRAM

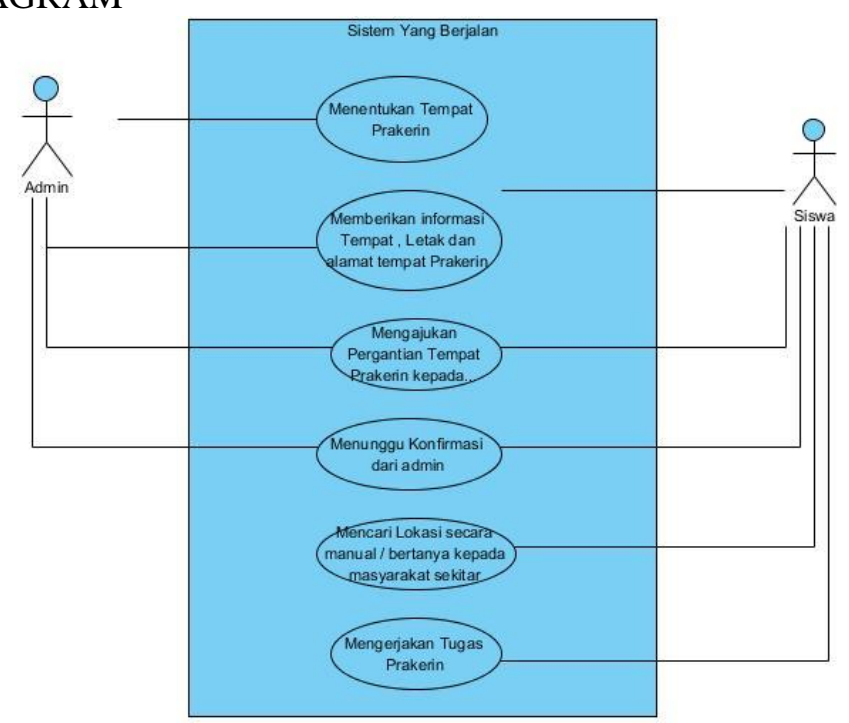

Gambar1. UseCase Sistem yang Berjalan

Berdasarkan gambar diatas maka dapat disimpulkan sebagai berikut:

1) 1 Sistem Prakerin.

2) 2 actor, yaitu: Admin dan Siswa

3) 6 Use case yang dilakukan oleh Actor - actor

B. ACTIVITY DIAGRAM

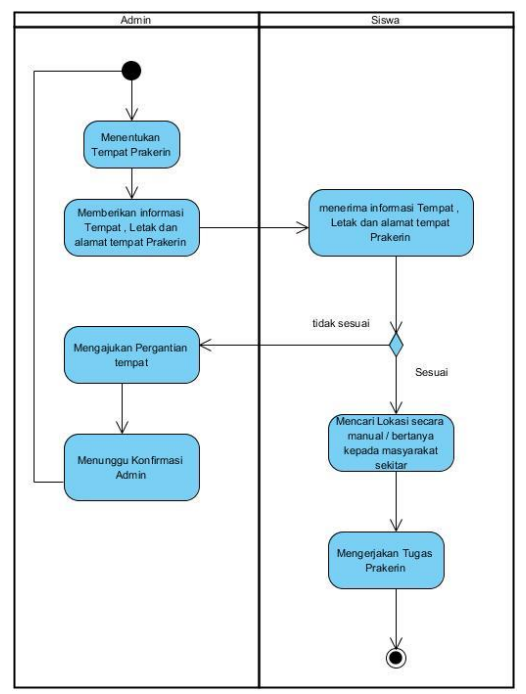

Gambar 2. Activity Diagram Sistem yang berjalan

Berdasarkan Tabel Activity Diagram diatas terdapat :

1) 1 Initial Node, Objek yang diawali

2) 2 Vertical Swimlane yaitu: Admin dan Siswa

3) 7 Action State dari system yang mencerminkan eksekusi dari suatu aksi 


\section{PERANCANGAN SISTEM}

Penerapan dari hasil analisa yang telah dilakukan oleh peneliti terhadap data yang diperolehnya, sehingga menghasilkan suatu rancangan sistem sesuai dengan kebutuhan dari pengguna. Pada tahap ini merupakan kegiatan mendesain dan merancang program sesuai dengan kebutuhan user, perancangansistem berlangsung selama waktu yang ditentukan.

\section{RANCANGAN SISTEM YANG DIUSULKAN}

A. Rancangan Login

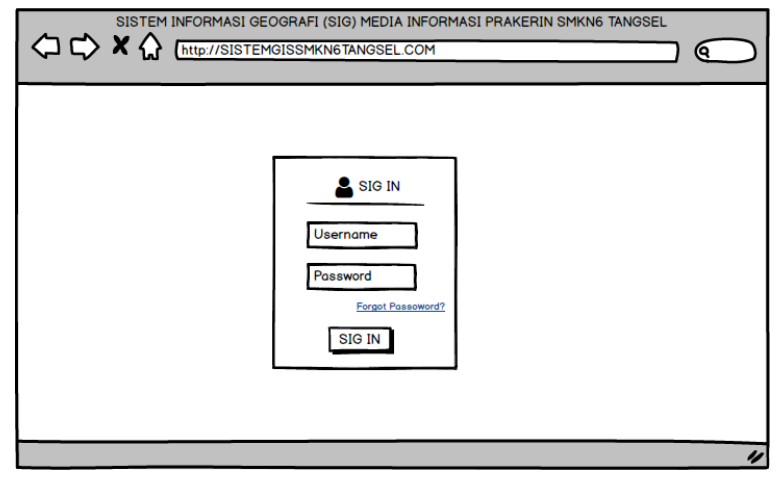

Gambar 3. Rancangan Login Admin dan Siswa

Pada gambar3. menggambarkan tampilan manu login awal apabila Admin ataupun Siswa ingin masuk ke menu harus memasukkan username dan password untuk setiap kolektor yang ingin login.

B. Rancangan Home

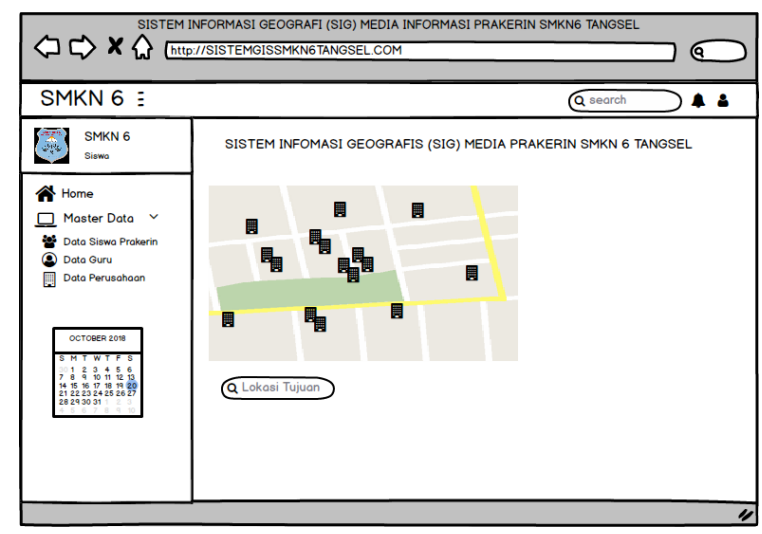

Gambar 4. Rancangan Home Admin

Setelah Admin / Siswa berhasil login, muncul tampilan home seperti pada gambar diatas, maka Pada Gambar 4. Pada Home admin Terdapat Peta di halaman utama untuk pencarian lokasi , Menu, data siswa, data guru, data perusahaan, input data siswa, input data guru, input data perusahaan .

Sedangkan Siswa hanya dapat melihat Peta di halaman utama untuk pencarian lokasi, data siswa, data guru dan data Perushaan .

C. Rancangan Tampilan Data Siswa 


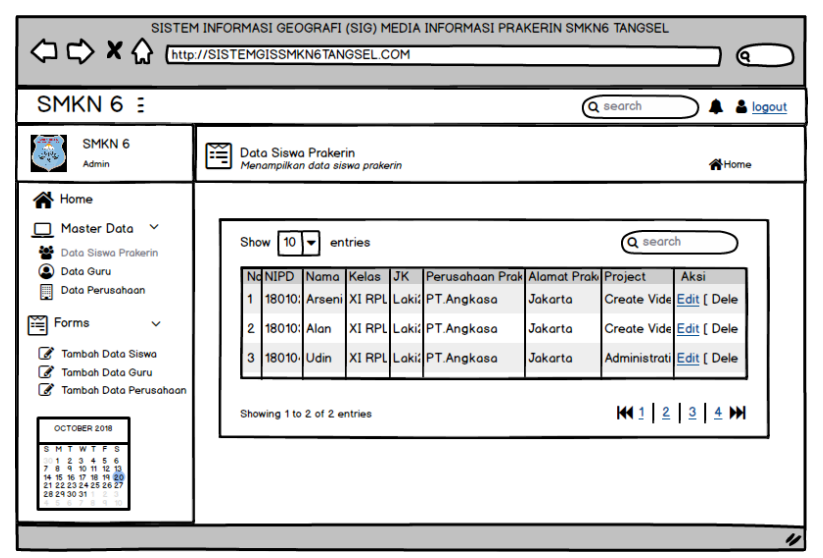

Gambar 5. Rancangan Tampilan data siswa

Pada Gambar 5. Menampilkan Seluruh data siswa yang telah maupun yang sedang melaksanakan Prakerin . Perbedaannya amin dapat Mengedit dan menghapus data sedangkan siswa hanya dapat melihat

D. Rancangan Tampilan Data Guru

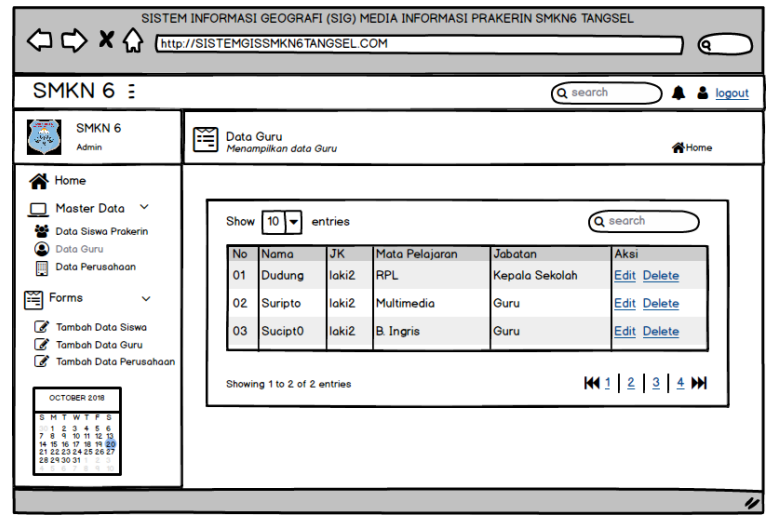

Gambar 6. Rancangan Tampilan data guru

Pada Gambar 6. Menampilkan Seluruh data guru yang terlibat pada Prakerin .Perbedaannya admin dapat mengedit dan menghapus data sedangkan siswa hanya dapat melihat.

E. Rancangan Tampilan Data Perusahaan

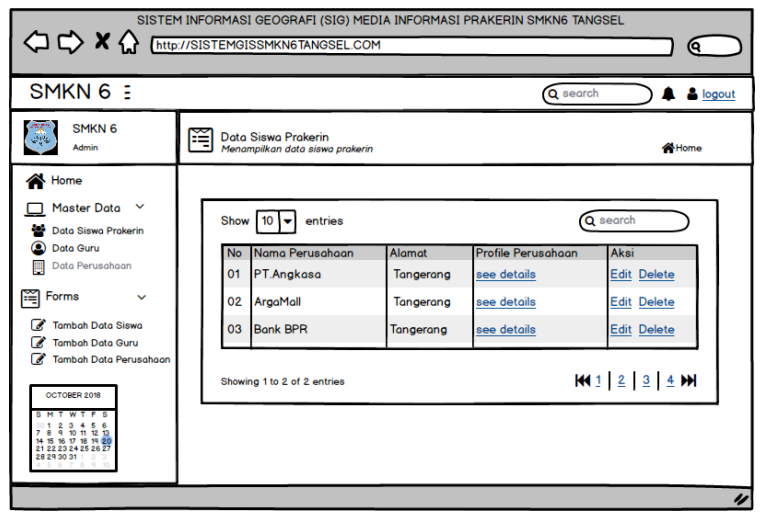

Gambar 7. Rancangan Tampilan data perusahaan 
Pada Gambar 7. Menampilkan Seluruh Perusahaan Prakerin .Perbedaannya admin dapat mengedit dan menghapus data sedangkan siswa hanya dapat melihat.

F. Rancangan Tampilan Input Data Siswa

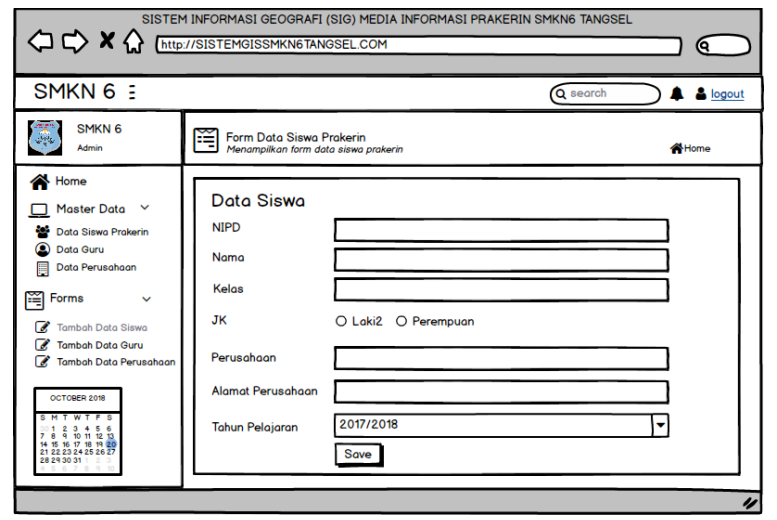

Gambar 8. Rancangan Input data siswa

Pada Gambar 8. Admin menginput, NIPD (Nomor Induk Peserta Didik), Nama Siswa, Kelas , Jenis Kelamin , Perusahaan Penempatan Siswa Prakerin, Alamat Perusahaan yang ditempatkan, Tahun Pelajaran .

G. Rancangan Tampilan Input Data Guru

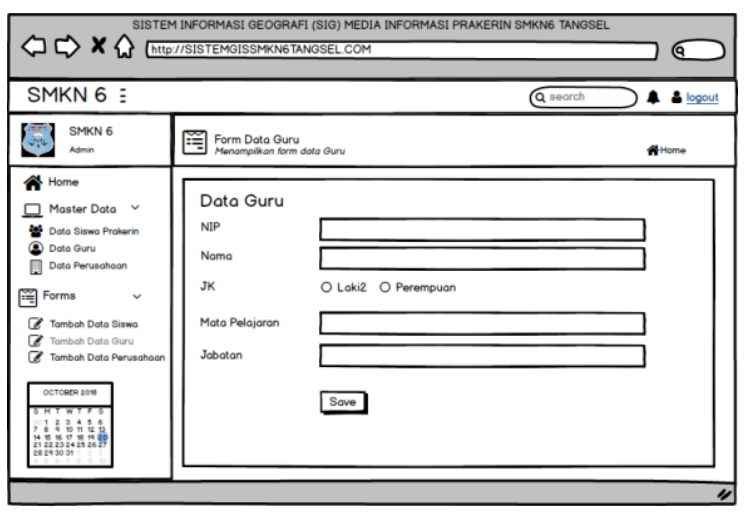

Gambar 9. Rancangan Input data Guru

Pada Gambar 9. Admin menginput, NIP, Nama Guru, Jenis Kelamin, Mata Pelajaran , Jabatan

H. Rancangan Tampilan Input Data Perusahaan

Vol 5 No 1 - Februari 2019 


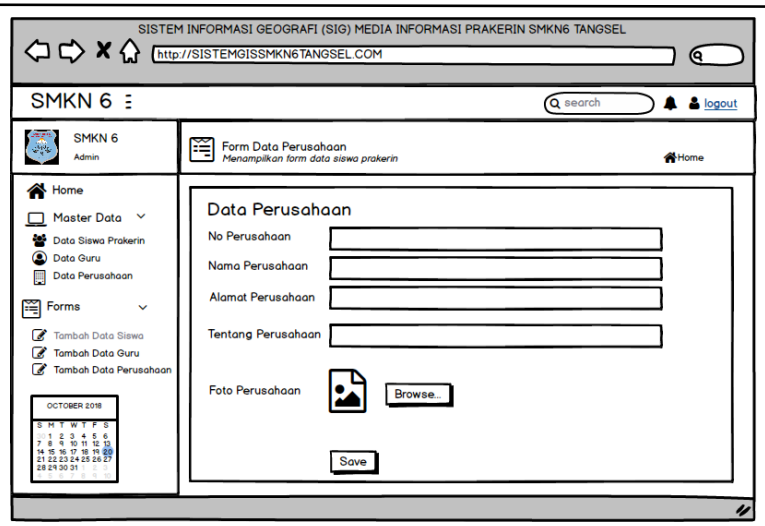

Gambar 10. Rancangan Input data Perusahaan

Pada Gambar 10. Admin menginput, No Perusahaan, Nama Perusahaan, Alamat Perusahaan , Tentang Perusahaan, Foto Logo Perusahaan .

I. Rancangan Tampilan Profile Perusahaan

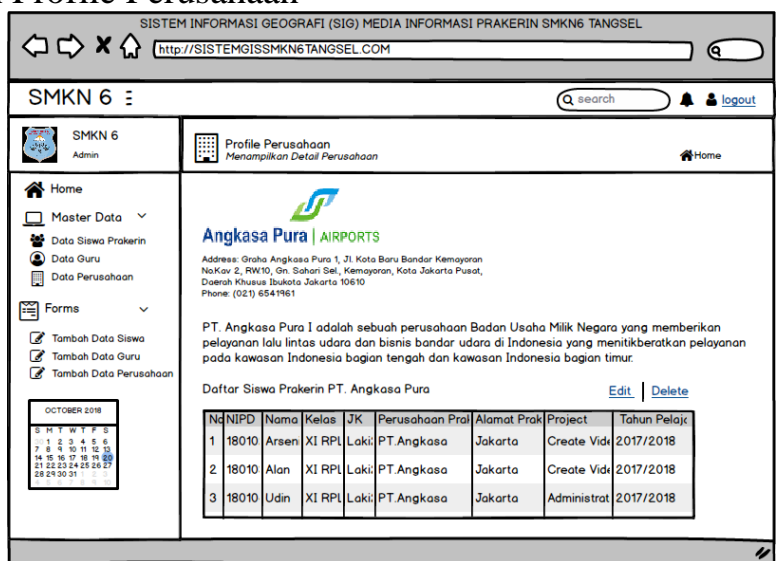

Gambar 11. Rancangan Tampilan Profile perusahaan

Pada Gambar 11. Menampilkan Profile Perusahaan Prakerin dan data siswa yang Prakerin disana . Perbedaannya admin dapat mengedit dan menghapus data sedangkan siswa hanya dapat melihat dan daftar untuk mengajukan pergantian lokasi prakerin .

J. Rancangan Tampilan Daftar

K.

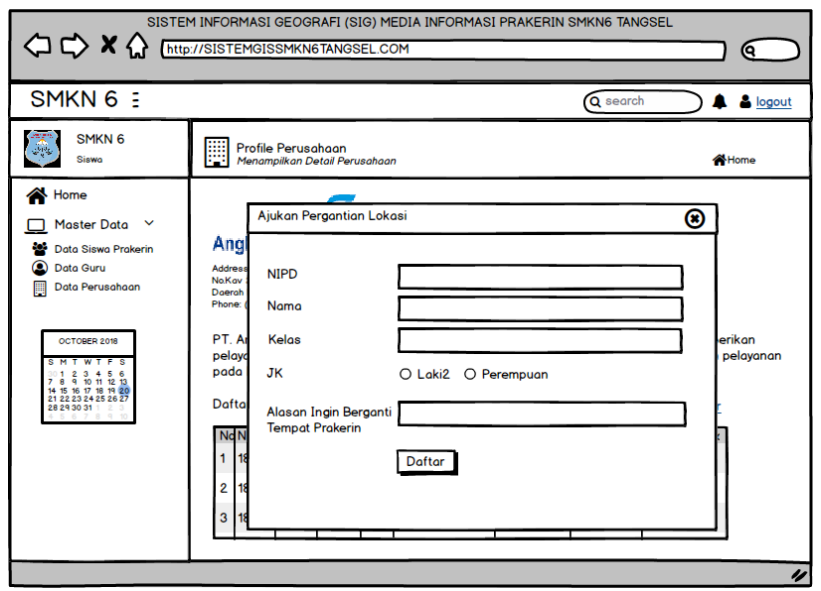

Gambar 12. Rancangan Daftar

Vol 5 No 1 - Februari 2019 
Pada Gambar 12. Siswa dapat mendaftarkan diri diperusahaan lain dengan mengisi form pergantian lokasi yang terdapat di link daftar.

L. Rancangan Tampilan Notifikasi

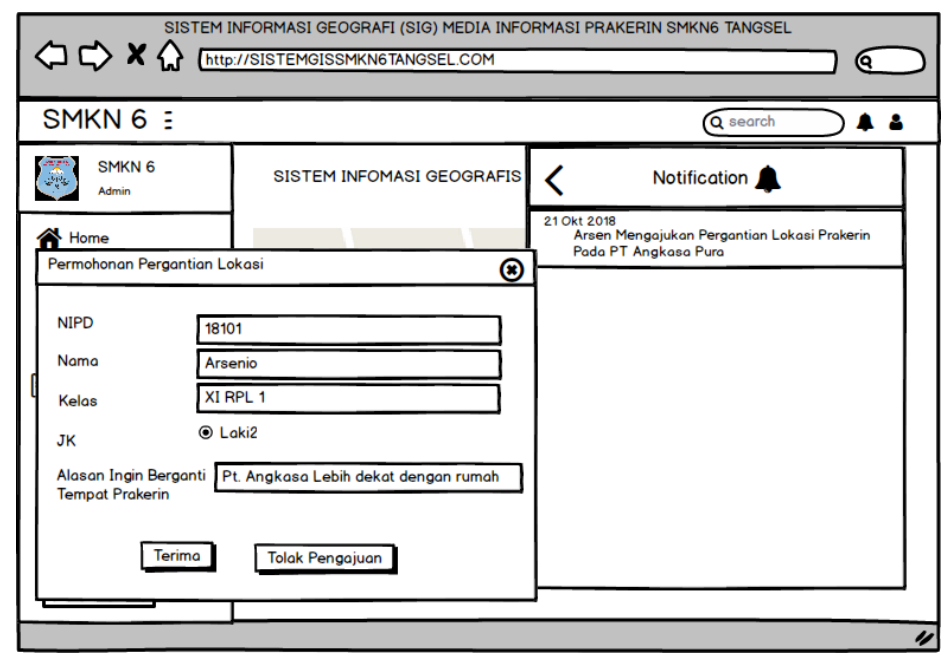

Gambar 13. Rancangan Notifikasi Admin

Pada Gambar 13. Notifikasi akan muncul jika ada siswa yang ingin mengganti lokasi prakerinnya . dan admin dapat menerima atau menolaknya dilihat dari alasannya .

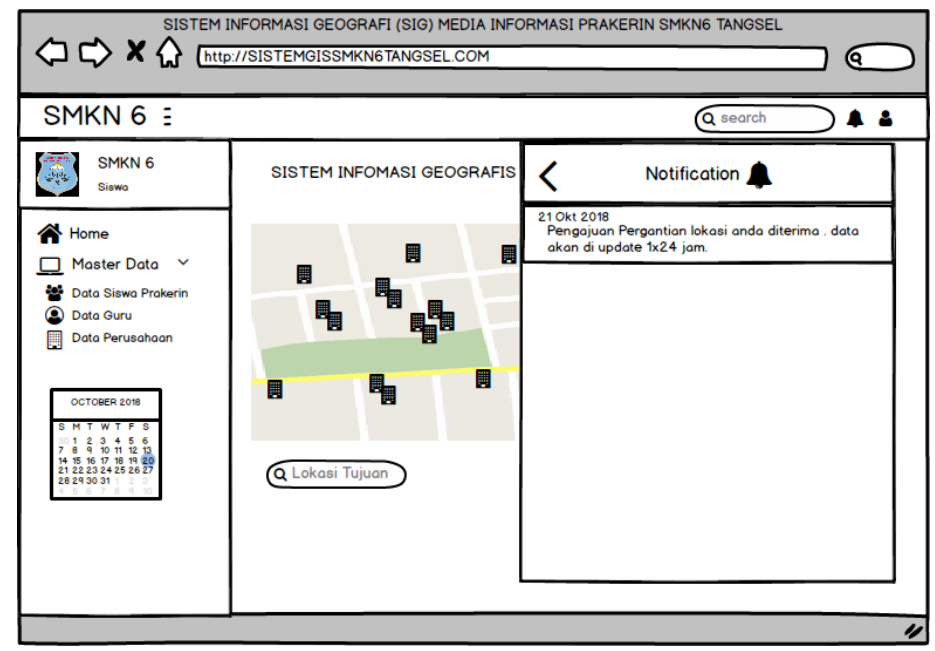

Gambar 14. Rancangan Notifikasi Siswa

Pada Gambar 14. Notifikasi akan muncul jika Admin telah menerima atau menolak pengajuan pergantian lokasi yang siswa pilih .

Setelah semua fungsi berjalan dengan baik serta program di anggap layak, maka langkah selanjutnya dilakukan uji coba implementasi program pada SMKN 6 Tangerang Selatan, uji coba implementasi program berlangsung selama waktu yang ditentukan. 


\section{KESIMPULAN}

Berdasarkan hasil penelitian yang telah dilakukan pada Sistem informasi geografis (Sig) sebagai media prakerin pada SMKN 6 Tangerang Selatan, maka penulis dapat menarik kesimpulan sebagai berikut :

1. Sistem informasi geografis (Sig) sebagai media prakerin pada SMKN 6 Tangerang Selatan yang berjalan saat ini dalam pengolahan datanya masih dengan metode pencatatan dikertas dan belum terkomputerisasi serta dalam pencarian lokasi prakerin siswa masih harus membuka google maps dan bertanya kepada masyarakat .

2. Sistem informasi geografis (Sig) sebagai media prakerin pada SMKN 6 Tangerang Selatan yang berjalan saat ini belum berjalan dengan baik dalam pengelolaan datanya masih sering terjadi kesalahan dan siswa masih ada yang kesulitan mencari lokasi sehingga mudah tersesat saat perjalanan menuju lokasi perusahan prakerin.

3. Untuk membantu siswa dan sekolah dalam mengelola dan memperoleh informasi mengenai prakerin dan jalur menuju lokasi Prakerin. Peneliti membuat sistem mengenai informasi prakerin yang dapat diakses dengan dan terdapat fitur jalur menuju Perusahaan Prakerin sehingga memudahkan siswa untuk tahu jalan mana saja yang harus di lalui menuju Perusahaa Prakerin.

\section{SARAN}

Untuk menangani masalah ini peneliti dapat memberikan beberapa saran sebagai bahan pertimbangan bagi SMKN6 Tangerang Selatan, diantaranya yaitu:

1. Diperlukannya sosialisasi agar sistem yang baru dapat digunakan dengan baik oleh user .

2. Meningkatkan tingkat keamanan dan pengontrolan sistem agar tidak mudah terjadi kerusakan dan tidak mudah terkena cyber crime seperti hack yang bisa terjadi pada sistem.

3. Mengembangkan Program yang telah ada menjadi lebih baik lagi.

\section{DAFTAR PUSTAKA}

[1]. Oleh Soleh , Nanda Dian Prasety dan Tatik Yuniati .2015 .Perancangan Sistem Sebaran Lokasi Pemerintahan Dengan Konsep Sistem Informasi Geografis Berbasis Web Pada Pemerintahan Kota Tangerang .Seminar Nasional Teknologi Informasi dan Multimedia .

[2]. Ahmad Mursyidun Nidhom, Ahmad Sonhadji K.H dan Dwi Agus Sudjimat . 2015 .Hubungan Kesiapan Belajar, Lama Pembelajaran, Kesesuaian Tempat dan Partisipasi DU/DI dengan Hasil Prakerin Peserta Didik Kompetensi Keahlian TKJ di SMk kota Batu.INVOTEC.

[3]. Al-Husain ,Felita Ariyanti dan Sinudarwati.2016 .Perancangan Database Relational pada Toko Buku Online. Jurnal Cerita Stmik Raharja .

[4]. Warnars, Spits. 2014. Perbandingan Penggunaan Database OLTP Dan Data Warehouse. Tangerang Jurnal CCIT Stmik Raharja .

[5]. Cosmas Eko Suharyanto, Dkk. 2017. Perancangan Sistem Informasi Penggajian Terintegrasi Berbasis Web (Studi Kasus di Rumah Sakit St. Elisabeth), . Jurnal Teknologi \& Sistem Informasi.

[6]. Fauzan Masykur .2014.Implementasi Sistem Informasi Geografis Menggunakan Google Maps API Dalam Pemetaan Asal Mahasiswa.Jurnal Simetris.

[7]. Mashita Enggar Kusuma, Yanto Budisusanto.2015. Aplikasi Google Maps API Dalam Pengembangan Sistem Informasi Geografis (SIG) Pariwisata Berbasis Web (Studi Kasus) Kabupaten Sidoarjo ). GEOID

[8]. Yusuf Muhammad, Ary Budi Warsito, Moh Iqbal Awi Makaram. 2015. Perancangan SIS+ Menggunakan Metode YII Framework Pada Perguruan Tinggi Raharja, Tangerang:Journal CCIT Stmik Raharja . 
[9]. Harfizar, dkk. 2017. Perancangan Sistem Informasi Pendataan Karyawan Pada Perusahaan Jasa Berbasis Web. Tangerang: STMIK Raharja. Jurnal CERITA . Stmik Raharja .

[10]. Ade Hendini.2016.Pemodelan UML Sistem Monitoring Penjualan Dan Stok Barang ( Studi Kasus : Distro Zhezha Pontianak) . Jurnal Khatulistiwa Informatika

[11]. Meta Amalya Dewi, Dede Cahyadi, Yunita Wulansari. 2014. Sistem Ujian Online Calon Mahasiswa Baru Berbasis I-Learning Education Marketing Pada Perguruan Tinggi . Jurnal CCIT Stmik Raharja 